\title{
BUDGET AND FISCAL POLICIES' MODERNIZATION AS A FACTOR OF NATIONAL COMPETITIVENESS INCREASE (THE CASE OF UKRAINE)
}

\author{
Yuriy Holynskyy \\ Ivan Franko National University of Lviv, Ukraine \\ Irina Onyusheva \\ Stamford International University, Thailand
}

Ukraine's economy, as compared to other neighbouring European countries, is lagging behind. Unstable political situation, significant tax pressure, various administrative barriers, complexity of tax administration and with obtaining permits, technical regulation, certification and standardization, frequent sudden inspections by state control bodies, limited opportunities for the use of financial and credit resources, weakness of material, technical, financial, managerial and personnel components of business entities - all these factors do not promote the entrepreneurial initiative in this country. The key precondition for rising the prosperity level raising and effective social and economic development is strengthening the competitiveness of the national economy through the coordinated work of the state and its budget and fiscal institutions. This study reveals the theory and the methodology of the formation and implementation of fiscal policy in Ukraine. Peculiarities in the development of the entrepreneurial environment in Ukraine are analysed and fiscal mechanisms are defined with the purpose of activating further entrepreneurship development.

Keywords: budget; taxes; fiscal policy; entrepreneurship; competitiveness; Ukraine

\section{Introduction}

The key precondition for raising the levels of prosperity and overall socioeconomic development is strengthening of the competitiveness of the national economy through the

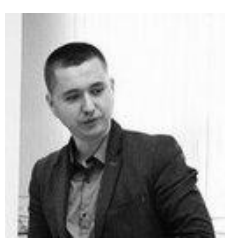

Yuriy Holynskyy

$\mathrm{PhD}$, is an Associate Professor at the Department of State and Local Finance, Faculty of Financial Management and Business, Ivan Franko National University of Lviv, Ukraine. His scientific interests are public finance, problems of budgets maintenance, state treasury services and functioning, fiscal policies at emerging markets. He is also the author of scientific monographs and book chapters on public finance published by the Ivan Franko National University of Lviv, Ukraine.

Email : yuriy.holynskyy@gmail.com

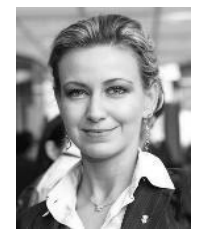

Irina Onyusheva

Dr., Prof., Turan University, Almaty, Kazakhstan; Stamford International University, Bangkok, Thailand Interests - Economics, Strategic Management, Formation, ensuring and increasing economic competitiveness on both micro- and macro- levels; Human Capital development; HR Management; Knowledge Economy; Knowledge Management; Project Management; Management in Education 
coordinated work of the state and its fiscal institutions. Taxes are one of the most important elements of fiscal policy, without which the state cannot effectively perform its functions. Taxes also affect the development of entrepreneurial activity, the redistribution of gross domestic product, changes in the structure of demand and consumption, quality of life for general population in the country. Moreover, they determine the conditions for the national economy's interaction with the outside world.

Dynamic spread of economic globalization during the last decade, namely liberalization of international trade and capital movements, the growing role of information in the development of society and the spread of deregulation, all have led to the development of international trade, increase of the production factors' mobility and to frees flows of capital between the states.

Contemporary processes of globalization are both the driving force and the result of the processes of cultural, political and, above all, economic integration. Economic integration is characterized by some essential features that in aggregate distinguish it from other forms of economic interaction between countries: interpenetration and interweaving of national production processes; wide development of international specialization and cooperation in production, science and technology on the basis of the most progressive forms of cooperation; deeper structural changes in the economies of the participating countries; the need for purposeful regulation of the integration process, development of well coordinated economic strategy and policy; regional character of spatial integration due to the fact all necessary prerequisites for this type of integration predominantly exist between the countries that already have close economic ties due to the factor of geographical proximity.

The result of these processes is the emergence of competition not only at the market of goods and services, but also within the tax environment. Inflexible and uncooperative behaviour of the states while establishing taxes, determining their composition, structure and mechanism of collection on their territory leads to the emergence of differences between the countries in terms of tax burden. Liberalizing tax laws, governments are trying to attract foreign investments, but at the same time, they prevent the outflow of the taxpayers abroad. The key result from these constant changes in countries' taxation policies is the emergence of international tax competition.

The main purpose of this study is to describe the theoretical basis and the methodology of the formation and implementation of budget and fiscal policies in Ukraine, so that to formulate the possible ways of improving the efficiency of the related regulation which, in turn, will lead to the increase of entrepreneurial activity and thus, higher country's competitiveness of Ukraine. To achieve this purpose, the following objectives should be complete: to analyse the results of budget and fiscal policies of Ukraine and its position in the selected international ratings; to reveal the instruments of budget and fiscal policies in Ukraine; to uncover the current and potential threats to local budgets' execution and fiscal decentralisation in Ukraine; to offer the ways of improving budgetary and fiscal policies in Ukraine and provide other related recommendations on the basis of the obtained data. 


\section{BUDGET AND FISCAL POLICIES' MODERNIZATION}

\section{Instruments of Budget and Fiscal Policies of Ukraine}

State regulation of the economy is carried out with certain fiscal leverage instruments in the process of fiscal policy implementation. Effectiveness of the state regulatory policy which is aimed at economic development depends on the correct choice of leverage or the combination of levers in complex. In contemporary economic literature, fiscal policy is associated with government regulation of state spending and taxation. For example, wellknown American economists K. McConnell and S. Brue argue that fiscal policy is a change in government spending and taxation, aimed at achieving full employment and noninflationary internal production (Rios et al., 2013). R. Dornbusch and S. Fischer suggest the following definition: fiscal policy is a government policy that deals with the volumes of government procurement, transfer payments and taxes (Dornbusch \& Fischer, 1986). Some other researchers under fiscal policy understand the process of changes in the taxation system, government expenditures in order to: first, reduce the fluctuation of business cycles; and secondly, contribute to rapid growth of high-employment economy and without high and uncontrolled inflation.

Some Ukrainian researchers (Krysovatyi, 2000) consider fiscal policy as the regulation of state expenditures and tax revenues to ensure full employment, price stability and economic growth, as we 11 as state influence on the economic situation by changing the taxation system of government expenditures. They argue that fiscal policy is the government's influence on the economy through taxation, formation of the volume and the structure of public expenditures in order to ensure adequate level of employment, prevent and limit inflation and the adverse effects of cyclical fluctuations. Other Ukrainian researchers (Bazylevych, 2004; Sidelnikova, 2010) believe that the budget and tax (fiscal) policy cover government measures aimed at ensuring full employment and production of non-inflationary GDP through changes in government expenditures, tax systems and approaches to formation of the state budget as a whole.

Fiscal policy can be also defined as a set of measures by which the state influences the economy through the structure of tax revenues to the state budget, directions of public expenditure and the methods of attracting borrowed funds.

In general, economic theory deals with two main forms of the fiscal policy functioning: automatic and discretionary, and the tools of these forms are: cost policy, income policy, tax system, transfer policy. Among the instruments of fiscal policy, researchers have identified primarily tax revenues, state expenditures and transfer payments.

The choice of fiscal adjustment instruments is primarily determined by the chosen model of market development. Thus, one of the key features of taxation in the United States, for example, is its relatively moderate level, but the level of spending by the state on the social sphere is also moderate. The European model is characterized by larger guarantees from the state, accompanied however by higher level of taxation. The highest level of GDP centralization is typical for Scandinavian countries, which are characterized by the largest public sector and the highest social guarantees. 
It should be noted that the choice of vector in fiscal regulation, the use of its instruments is determined by the peculiarities of the institutional environment, as well as fiscal traditions that have been evolving for decades. Consequently, implementation of the fiscal control mechanism involves the use of two main groups of levers - budgetary and tax, which are implemented through the use of appropriate instruments. In scientific literature, different approaches to interpretation and classification of fiscal instruments are considered. In particular, fiscal instruments can be categorized as: restraining (budget deficit, excessive tax burden, minimal level of local taxation etc.), equalizing (various subsidies and subventions), stimulating (tax privileges, reduction of tax rates etc.). Also, there are budget levers, which include budget expenditures (budget loans, budget investments, subsidies, subventions, subsidies, expenditure structure) and budget deficit (size of deficit, method financing of the deficit), as well as tax levers: tax rates (tax burden, investment tax credit, investment tax discount, reduction of tax rates, decrease in the value of the taxation object), tax privileges (tax holidays, tax exemptions for certain transactions, exemption from taxation of individual taxpayers), alternative tax regimes (simplified tax system, special free economic zones), changes in tax payment deadlines (deferred payment, instalment payment), tax sanctions (fines, penalties, cancellation of preferential tax treatment).

Fiscal instruments are divided into: systemic (level of taxation, structure of the tax system, application of alternative taxation systems), complex (special tax regimes for certain groups of taxpayers, special tax regimes for certain sectors of the economy), local (tax objects, taxpayers, tax rates, tax calculations, tax credits).

Instruments of fiscal policy include fiscal norms and periods for fulfilling obligations to the state. Such standards are rates, tariffs, taxis, inflation rates etc. The mentioned periods include the terms of submission of declarations, terms of payment, payment of debts etc. Incentives include benefits, instalment payments, and tax credits. Levers of influence on payers are fines and penalties. The instruments of fiscal policy include the degree or the nature of its levers, in particular, the rigidity of the use of such instruments, high rates of taxation, high levels of fines or the liberalization of this policy, in particular, reduction of the level of fines imposed on business entities.

It can be noted that over the past years the role of indirect taxation in Ukraine has intensified. Thus, during the investigated period, tax revenues to the Consolidated Budget of Ukraine increased by 2.6 times, while the volume of indirect taxes alone - by 2.9 times. Thus, the share of indirect taxes in the overall structure of tax revenues increased from $49.6 \%$ in 2010 to $55.0 \%$ in 2016.

Among the indirect taxes, the largest share belongs to the value added tax $-65.9 \%$. This tax forms one third of the overall budget revenues and tax payments. The share of excise tax in indirect taxes is $28.4 \%$, in budget revenues - $13.0 \%$, in tax revenues $-15.6 \%$.

The transfer of a larger share of taxation on consumption is a popular pan-European trend, it is used to increase the share of profits at the disposal of taxpayers. 


\section{BUDGET AND FISCAL POLICIES' MODERNIZATION}

Among the direct taxes, the tax on personal income is dominant; its share in Ukraine is 47.3\%. During the investigated period, the receipts of this tax into the Consolidated Budget of Ukraine increased by 2.7 times. The corporate income tax covers $20.5 \%$ of all direct taxes, $7.7 \%$ in budget revenues, and $9.2 \%$ in tax revenues. In recent years, the fiscal role of corporate profit tax has decreased though.

Domestic personal income tax and corporate income tax rates are among the lowest in Europe - $18 \%$. For example, less than in Ukraine the corporate income tax is in Ireland (12.5\%), however, the offset there is represented by higher PIT rates (up to 48\%) and VAT (23\%). Similarly, lower corporate income tax in Slovenia (17\%) is accompanied by the offset of higher PIT rates (up to 50\%) and VAT (22\%). In Romania, the rate of corporate tax and personal income tax is $16 \%$, while the VAT rate is $24 \%$.

The lowest tax rates in the EU (10\%) - in Bulgaria - over the past few years did not provide significant economic growth but only sharply increased the budget deficit and, as a result, led to increasing public debt. Among the 28 EU Member States, 17 countries have the VAT rates above the Ukrainian level, equal level (20\%) have 7 countries, and only 4 countries in Europe have VAT rates lower than in Ukraine (Luxembourg, Malta, Germany and Cyprus). Thus, with the exception of small island countries and the Baltic countries, Ukraine has the most attractive tax rates, which should become an important prerequisite for attracting foreign investments and creating new jobs.

The state, using the tools of fiscal policy and the methods of its implementation, should regulate the reproductive process on the production, technical and technological basis of enterprises, promoting at the same time the creation of the market most favourable and adaptive conditions for all market participants to get involved in innovation and investment activities. Provision of state privileges must be oriented on the priority of financially advantageous for the state spheres and sectors.

In addition, fiscal policy in Ukraine is aimed at the maximal withdrawal of funds from taxpayers, which actually deprives business entities of profit - the main motive of their activities. As a result, this narrows the possibility for accumulation of funds that could be later invested in the development of the production base, therefore, it also may lead either to bankruptcy of enterprises, or to their decision to move to the shadow sector of the economy.

Excessive tax burden leads to more and more shadowing of business activities. While reducing tax burden contributes to economic growth of the state through increased real incomes, additional household savings, effective demand etc.

Shadow economy has its negative impact on all socioeconomic processes taking place in society, causing serious mistakes while determining the main macroeconomic indicators, leading to inadequate assessment of the most important processes and trends, tactical and strategic failures in ensuring the competitiveness of the economy. According to many experts, the level of shadow economy in Ukraine is very high. This negatively affects the volume of revenues to the budgets of all levels, the ability of the state to implement large- 
scale investment and social projects, social protection of employees and disadvantaged social groups, as well as the effective use of natural and financial resources of the country.

In order to reduce the level of shadowing in Ukraine, it is necessary to redirect the tax policy on the implementation of the following priorities: ensuring equal taxation conditions for all economic entities, reducing tax burden, ensuring effective tax administration and stability of public finances overall.

The objective of the fiscal policy is to establish such an optimal level and taxation conditions that ensure efficient business activity of economic entities and the reasonable balance between the interests of the state and the taxpayers.

According to the Annual Business Climate Assessment (ABCA) conducted in 20152016, the index of business climate in Ukraine is at the level slightly above 0 on the scale from -1 to +1 (Freik et al, 2017). The survey of entrepreneurs allowed creates the list of the main obstacles to business development. The first place in the rating is occupied by the group of factors, which includes the consequences of the military aggression of the Russian Federation and the general instability of the political situation in the country $(59 \%$ of all respondents mentioned them). The second place is occupied by the problems related to tax legislation, in particular: complexity of tax administration, frequent changes in legislation, frequent changes in tax and other forms of reporting (54\% of the respondents' answers).

Instability and frequent changes in tax legislation create tensions in fiscal authorities' relations with taxpayers, reduce economic activity of business entities, thus slowing down economic growth in the country in general.

Typical tax administration problems can be identified as follows: insufficient transparency of the system of electronic administration for VAT and delays with returning budget compensations prior to its implementation, unilateral cancellation (by the fiscal service) agreements on the recognition of electronic documents; violation of the moratorium on tax audits of taxpayers with an income volume of up to UAH 20 million for the previous calendar year; appointment of tax audits in the absence of sufficient grounds, procedural violations during audits or making unreasonable decisions on their results; ineffectiveness of the administrative appeal procedure - limited time to appeal for taxpayers, formal approaches on the side of tax authorities, limited personal liability of tax officials.

Tax and customs services are currently on the top of the anti-rating of public authorities in terms of corruption, although in other parts of Europe they usually have much high degrees of trust, professional image and authority. Under all these conditions, shadow economy and corruption are more economically advantageous for Ukrainian entrepreneurs, since both of them help avoid punishment for tax evasion.

Thus, under the negative influence of systemic deformations on the economy, for most enterprises and entrepreneurs, the only way to ensure business continuity becomes concealing part of income from taxation, thus violating the principles of business social responsibility and legal obligations to the state and the society. 


\section{BUDGET AND FISCAL POLICIES' MODERNIZATION}

One of the most acute problems with Ukrainian fiscal policy is financing of budgets and cost optimization, especially during the economic crisis. Improving fiscal policy should increase the competitiveness of Ukraine's economy, activate the innovation and investment component of its development, and positively influence the structural processes in the real sector economy, thus providing more dynamic economic growth overall as well as increasing level in life quality.

Formation of an innovative model of the economy is impossible without the use of complex state incentives, primarily fiscal ones. This is because investment in innovation is associated with additional risks, thus the expected profit is supposed to compensate for that. Advantages of tax instruments today are an integral part of any tax system in any country of the world. Noteworthy, 26 of 34 OECD countries offer tax incentives for the businesses that are implementing $R \& D$ activities.

Among the countries outside OECD, this practice is also actively used by Brazil, China, India, Russia, Singapore, South Africa and some other countries. Tax incentives, such as investment tax credit, research tax credit, investment tax discount are most effective and most common tools for supporting and stimulating innovations. Prevalence of these instruments of tax support for investment and innovation activities can be explained by their attractiveness for both the state and the enterprises.

Tax preferences for capital investments are often realized in the form of an investment tax credit to those enterprises, which are performing direct investments in new technologies, techniques, equipment etc. An investment tax credit is available only after the fact of implementing new equipment into operations, and the size of this credit is determined as a percentage of the cost of the equipment being introduced: for electronic equipment and equipment in Japan it is 5.3\%; for new technology, technologies, materials of the first year in operation in the UK - 50\%. In the United States, tax deduction for such investments is limited to energy-saving equipment exclusively.

Improving the quality of effectiveness assessment in using tax incentives involves improving the process of disclosure of statistical information and tax analytics by sectors of the economy, defined in the state programs. This will ensure transparency and openness in the formation of budget investments. Tax benefits should be based on the assessment of innovation and investment activities in top-priority sectors of the economy. It is expedient to determine the nature of tax incentives and the object of their influence, to create a single register of investment and innovation projects with a view to applying direct and indirect measures of state support for stimulating the economy. The improvement of the effectiveness of tax privileges will be facilitated by the improvement of financial instruments, including methods for analysing, evaluating and financing innovative and investment activities of organizations (based on foreign experience).

The purpose of fiscal policy is to ensure appropriate level of socioeconomic development for the society, taking into account the balance of public finances, implemented through the institutions of budgetary regulation and state financial control. 
State regulation in today's conditions is a macroeconomic regulator of reproductive processes, aimed at implementation of strategic priorities of socioeconomic development of the state. Long-term forecasting of budget expenditures is an important instrument in state regulation of economic and social processes, since it substantiates the directions of using budget funds in the future, taking into account the determined goals and priorities of the country's socioeconomic development in the medium and long term.

Regulation in the field of budget expenditures through the use of a combination of budgetary tools of influence on the process of formation and execution of the budget allows copying with the challenges faced by the country at the present stage of social development, achieving at the same time the necessary macroeconomic proportions and indicators of economic growth. Increasing certain levels in the competitiveness of country's economy, in quality of public services, and in living standards requires the implementation of a strategy optimizing the amount of budget expenditures, while increasing their effectiveness.

Taking into account the level of budget filling in today's conditions, the urgent task would be to reduce budget deficit and increase the efficiency of using budget funds. This implies an increased share of public expenditures in the innovation sector of the economy; improving the public procurement system; program-target method use for optimizing the number of budget programs, determining their optimal structure and content; prevention of duplication in the functions assigned to various spending units; improvement of the budget program management process; raising the level of responsibility of the main spending units for violating the requirements of budget legislation.

The current stage in the development of budget relations in Ukraine is characterized by an increasing role of budgetary expenditures in the process of regulating the socioeconomic development of the state and regions.

Budget expenditures are involved in formation of consumption and accumulation funds in the state, therefore, they are an important area of influence on economic and social processes. In general, fiscal policy in the field of public expenditures is a rather powerful instrument for influencing socioeconomic development, especially in the context of economic reforms and limited financial resources of the state.

To determine the role of budget expenditures as a fiscal policy tool, efficiency of the budget resources' distribution, impacts of certain their components on economic situation of the state, peculiarities of the budget expenditures' formation in recent years in Ukraine were analysed.

The analysis of the dynamics of the share of expenditures on economic activity in the total expenditures of the consolidated budget shows that for the last nine years the largest their share - $17.9 \%$ was observed in 2007, and the lowest - 7.9\% - in 2016. Also observable is the decrease in the share of budget financing of the economy to GDP - from 5.6\% in 2007 to $2.8 \%$ in 2016 . 


\section{BUDGET AND FISCAL POLICIES' MODERNIZATION}

At the same time, in 2016, capital expenditures were only $8.8 \%$, thus demonstrating a gradual fluctuation between $3.9 \%$ in 2014 and $10.1 \%$ in 2007 . This reflects the practice of redistributing budget resources, mostly on the side of current expenditures.

The extremely low share of capital expenditures in the budget indicates the prevalence of a short-term development strategy, while most of institutional changes in a developing economy can be achieved through directing budget funds on capital expenditures, in particular, on innovations. Since there is a need to reorient the economy of Ukraine onto a more innovative way of development, attention should be paid to the efficiency of financial resources' redistribution in the state, in particular, on stimulating innovative projects, partly through budget expenditures on innovation and preferential taxation of certain areas of activity and industries. Budget expenditures on infrastructural changes, as well as the costs of innovation, also have their positive impact on long-term economic development. Spending on innovations can help maintain the scientific and industrial potential of the country on a required level.

We have also analysed the dynamics of the key macroeconomic indicators for the years 2007 to 2016, which affect the budgetary system of Ukraine, as well as its interaction with fiscal policy. Inter alia, we have studied GDP and its components, namely, consumption, accumulation, export and import of goods and services.

The structure of Ukrainian economy shows that the volume of investment in the country is insignificant as compared to the level of consumption. This is yet another proof for the need to perform structural reforms and thus guide national economy on the more innovative path of development, thus ensuring more active economic growth.

The generally known constraints to the country's economic development and its low investment attractiveness are inconsistency and unpredictability of the legislative and regulatory environment in Ukraine.

To the major problems at the current stage of the fiscal policy implementation in Ukraine belong: prevalence of fiscal tasks over the regulatory potential of tax instruments, inefficient use of state financial resources mobilized through both tax and debt sources, imbalances in the interbudgetary fiscal and social transfers, which adversely affect macroeconomic stability.

Potentially increasing competitiveness of the national economy depends, first of all, on active investment and fiscal policies and, therefore, further improvement of fiscal instruments becomes a particularly important aspect of socioeconomic transformations in Ukraine. The main precondition for the state's competitiveness is a well regulated, effective, stable fiscal policy that meets European aspirations and contributes to attracting potential investors to Ukrainian economy.

\section{Threats of Local Budgets' Execution and Fiscal Decentralisation in Ukraine}

Taxes are mandatory payments to be made by legal entities and individuals to budgets of various levels. Historically, they are the oldest form of financial relations between the state 
and the members of society. Foreign economic activity, including the inflow of foreign investments, can be regulated using taxes. With the help of taxes, the state receives the resources needed to carry out its public functions. Taxation system determines the final distribution of incomes inside a society.

The main objective of tax revenues is to provide the state budget with financial resources to finance public expenditures. Formation of tax revenues is carried out by budget mobilizing taxes, duties, and other compulsory payments. The size of such tax revenues depends on the state of the country's economy, as well as on a country's needs for redistribution of GDP and financial support in the course of state programs' implementation.

However, the state lacks state budget revenues to fully finance expenditures, especially in Ukraine in recent years, since the deficit of the State Budget of Ukraine has grown rapidly. Threats to financial and economic security of the state have its disabling effect on the taxation of economic activity of business entities, as well as unplanned budget losses due to the lack of tax revenues.

The effects from the unbalanced tax policy can generate the following threats to financial and economic security of the state:

- the growing share of the shadow economy;

- constantly increasing level of the tax debt;

- illegal use of tax privileges;

- illegal manufacturing and further same illegal sale of the supposedly excisable goods;

- tax evasion;

- carrying out fictitious foreign economic operations.

Also, there are additional factors lowering the levels of both financial and economic security. They include:

- ill-conceived tax policy;

- high level of taxation imposed on business entities, which restrains the growth of entrepreneurial activity (especially in the field of innovation production);

- corruption in tax administration.

Another threat to financial and economic security of Ukrainian economy is the uneven distribution of tax burden in the country, which is caused, above all, by the imperfection of the mechanism used for granting tax privileges. The major problem with the domestic taxation system is the extremely large number of taxes and the permanent variability of their list.

The instruments of fiscal regulation are not an effective means of rising the level of economic security in Ukraine, in opposite - it generates a number of additional threats to the domestic economy.

An important role in the system of budgets execution is allocated to local budgets. The problems with forming the revenue base for local budgets, the lack of financial resources for local authorities and the instability of their sources of income are acute in Ukraine. 


\section{BUDGET AND FISCAL POLICIES' MODERNIZATION}

Ukraine lacks an effective system of fiscal regulation over the economic security of its regions. The main threats in this regard are as follows:

- excessive centralization of the financial system, redistribution of a significant amount of financial resources through the state budget;

- insufficient financial support of local authorities and their high dependence from the state budget when it comes to formation of revenues (70-80\%);

- lack of real decentralization, as it is evidenced by the growing role of transfers in the formation of local budget revenues and the declining share of local revenues in the consolidated budget of the country.

Local budgets in Ukraine depend on the financial assistance in the form of intergovernmental transfers. The lower levels of government authorities in the country are entrusted with the functions of providing public services of vital importance; however, their execution is not supported with the sufficient volume of financial resources. In addition, local budgets' capacity to form their own revenue base is limited by an ineffective institutional environment (Holynskyy, 2013).

One of the main reasons for unsatisfactory financial situation of local authorities in Ukraine is the inefficient functioning of the local taxes and fees institute, which is influenced by such exogenous and endogenous negative factors as: limited list of local taxes and fees; general ineffectiveness of the tax imposed on the real property other than land; restriction in the rights of local authorities in part of having own fiscal policy and, in particular, in establishment of local taxes and fees; lack of incentives for local self-governments to increase the revenue base in the areas under their administration.

The Tax Code of Ukraine has modernized the system of local taxes and fees. But these relatively recent changes in it did not contribute to strengthening the financial base of local budgets. Such a situation requires immediate development and implementation of a state program which would increase the level of economic security. Inter alia, this program is supposed to include the use of fiscal instruments. Priority in this regard belongs to the development of appropriate regional targeted programs, fiscal decentralization, clear division of powers between national and local authorities, improvement of the system of intergovernmental fiscal transfers etc.

Thus, an important way of improving the efficiency of fiscal regulation over the economic security of Ukraine's regions is fiscal decentralization. Fiscal decentralization in Ukraine stems from the numerous changes taking place due to the newer versions of the Tax and Budget Codes and other legislative acts. The first steps in this tax reform concerned the reduction in the number of taxes overall. In particular, the number of local level taxes reduced due to combining 17 taxes into 7 .

\section{Ways of Improving Budgetary and Fiscal Policies in Ukraine}

Increasing budget revenues without creating additional barriers to economic growth would be possible within the following policy areas: 
- Increasing the tax burden on consumption, rather than on capital. In terms of the threat of critical imbalance in the system of public finances, it is necessary to be prepared to increase some taxes. At the same time, it should be clearly understood that the increase of direct tax rates reduces the financial result and limits the innovation and investment opportunities of entities. Because of this, most of the developed countries, while trying to solve the problem of budget deficit, increase indirect taxes, primarily taxes on consumption. Fiscal efficiency of taxes on consumption is higher, since they are charged only in case of actual consumption. This means that this type of taxes cover not only official sources of income but also those received within shadow economy. Therefore, in the case of Ukraine it would be necessary to shift emphasis from taxation on capital to consumption taxation, since here there is a great potential for tax revenues' growth.

- Refusal to further reduce the tax rate on profit. In Ukraine, the profit tax rate is already one of the lowest in comparison with the EU countries, therefore, its further reduction is no longer appropriate. This can be also substantiated by the fact that the reduction of fiscal pressure on profit will not automatically lead either to an increase in investments, or to expansion of current activities' volume. The accumulated experience of European countries suggests that the reduction of income tax rate and introduction of a single income tax rate were effective while the inflow of foreign direct investments grew intensively. And when revenues halt, it turned out that the countries with the lowest tax rates were affected by the global financial and economic crisis more severely than the others. This is due to the fact that reduction of the income tax rate did not contribute to a corresponding increase in the volume of attracted investments into the country, and a larger share of additional profits was used for other needs, in particular, on dividends.

- Refusal to further reduce the basic VAT rate. Experience of many other countries testifies that in order to increase tax revenues to the EU budget they raised the VAT rate first of all. In particular, Italy, Spain, Ireland, Czech Republic and Hungary have made such a decision during 2012-2013. Even if by reducing the tax rate it will be possible to save budget reimbursements over a certain period of time, the VAT rate in Ukraine will be the smallest in comparison with other post-socialist countries of Central and Eastern Europe, and this fact in the future will reduce the share of indirect taxes that is unusual for market economy as such. It is necessary to raise the VAT rate temporarily to $23 \%$ with the simultaneous introduction of a $10 \%$ rate for essential goods. The majority of the EU countries that, in the times of crisis, faced the need to finance additional budget expenditures, ended up with introducing the increased rate $(23 \%)$ of VAT on luxury goods permanently. It would be expedient to add the following items to the list of objects under higher VAT rate: purchasing cars with larger engines, yachts, jewellery, valuable watches etc.

- Optimization of the tax privileges system. Tax benefits should be directed towards the development of those segments of the economy, which in the future will lead to increased incomes or reduced costs due to production modernization, issuing new products or 


\section{BUDGET AND FISCAL POLICIES' MODERNIZATION}

improving significantly their quality, thus raising the competitiveness level overall. In addition, it is also important to ensure:

- the list of industries subject to tax incentives is regularly reviewed. These and other tax benefits should be provided to enterprises that own, use or develop high technologies, since the latter is the best guarantee for the long-term high rates of economic activity. And this, in its turn, would be replenishing the state budget via tax revenues;

- there are exact and specific criteria for granting tax privileges. One of the consequences from the current ineffectiveness of providing tax benefits is the significant loss of budget revenues. Therefore, it would be necessary to take the following into account while changing the system of tax privileges in Ukraine:

- when tax benefits are provided, type of enterprise activity should be considered, potential impact from these benefits should be assessed along with the relevance of their use. Also, potential budget losses from these benefits' imposing must be calculated along with the impact on the country's socioeconomic development;

- strategic objectives of imposing particular tax privileges must be clearly defined. Future compensation for the tax revenues not received by the budget should be accurately calculated, accounting for production modernization, introduction of new products or improvements in quality and competitiveness of the already existing ones;

- one of the main preconditions for granting tax privileges should be mandatory finishing of an investment project;

- stronger control over the use of tax incentives. Tax evasion schemes exist in Ukraine in their wide variety, so it is necessary to find effective methods for monitoring the use of tax breaks. Due to the abuse of tax privileges and purposeful use of tax-deductible funds to increase production, re-equip material and technical base, introduce the latest technologies, it is necessary to consider the following:

- to ensure adequate state control over all related processes and to increase the responsibility for the misuse of the funds released from taxation;

- to introduce systematic reporting of the Cabinet of Ministers to the Parliament (Verkhovna Rada) on the amounts of tax incentives, as well as on economic and social efficiency of the granted tax benefits during a certain period.

- Improving the effectiveness of combating income concealment. Tax revenue office has quite wide powers to control the authenticity of the declared by citizens incomes and property, but work in this direction remains to be quite ineffective. At the same time, shadow incomes of citizens are nearly the only large source of potential budget revenues today. Shadow income of the society has a significant fiscal potential and what is more important, its integration into the tax system would not create barriers for further economic development;

- Deepening progression of the personal income tax, the key sources of which are wages and other forms of remuneration. Social privilege should be introduced into this system in the form of a reduced tax rate for low-income groups of population; 
- Introduction of a capital tax on the level of $1 \%$ of the market value of shares owned by residents of Ukraine;

- Extension of the list of minerals, mining and sale of which are charged with additional rent. In addition to oil, gas and gas condensate, Ukraine produces a significant amount of other valuable minerals, which are the property of the Ukrainian nation, actually, but at the same time they somehow do not generate income from the industrial development. It seems expedient to add iron ore, manganese ore, uranium ore, some varieties of coking coal, ores of non-ferrous metals etc to the list of minerals, mining and sale of which are subject to a special rent. This will significantly increase the volume of budget revenues.

- Extension of the group of excisable goods. In particular, objects of taxation in the category of excise goods should include the purchases of food products that are of premium category or harmful to health.

This would allow not only increasing budget revenues, but would also provide additional positive stimulus, in particular, those related to restriction on harmful food products.

\section{References:}

Bazylevych, V. (2004). Macroeconomics. Znannya. 690

Dornbusch, R., \& Fischer, S. (1986). The open economy: implications for monetary and fiscal policy. In: The American business cycle: Continuity and change. University of Chicago Press.

Freik, N., Bespalko, V., Fedets, I., \& Kuziakiv, O. (2017). Annual Business Climate Assessment 2016: National and Regional Dimensions. Retrieved from The Institute for Economic Research and Policy Consulting: http://www.ier.com.ua/en/sme_development/ABCA?pid=5789

Holynskyy, Y. (2013). Improvement of Cash-flow Planning by the Treasury of Ukraine. Economic Annals-XXI. 51-54.

Krysovatyi, A. I. (2000). Taxation and Market: the Conditions and Possibilities of the Combination. Vydavnytstvo Karpiuka. 11.

Rios, M. C., McConnell, C. R., \& Brue, S. L. (2013). Economics: Principles, problems, and policies. McGraw-Hill.

Sidelnikova, L.P. (2010). Tax and Credit Finance: Fiscal Philosophy of Choice. Hrin' DS.13.

Tyrrell, B., \& Riley, P. (2017). 2018 Index of Economic Freedom: Freedom to Trade Is a Key to Prosperity. Retrieved from The Heritage Foundation: https://www.heritage.org/sites/default/files/2017-11/BG3266.pdf

Ukraine: Economic Freedom Score. (2017). Retrieved December 10, 2017 from The Heritage Foundation: https://www.heritage.org/index/pdf/2017/countries/ukraine.pdf

World Bank (2018). Doing Business 2018: Reforming to Create Jobs. Washington, DC: World Bank. DOI: $10.1596 / 978-1-4648-1146-3$.

Paper submitted Paper accepted for publishing Paper published online
04 September 2018

26 November 2018

31 January 2019 